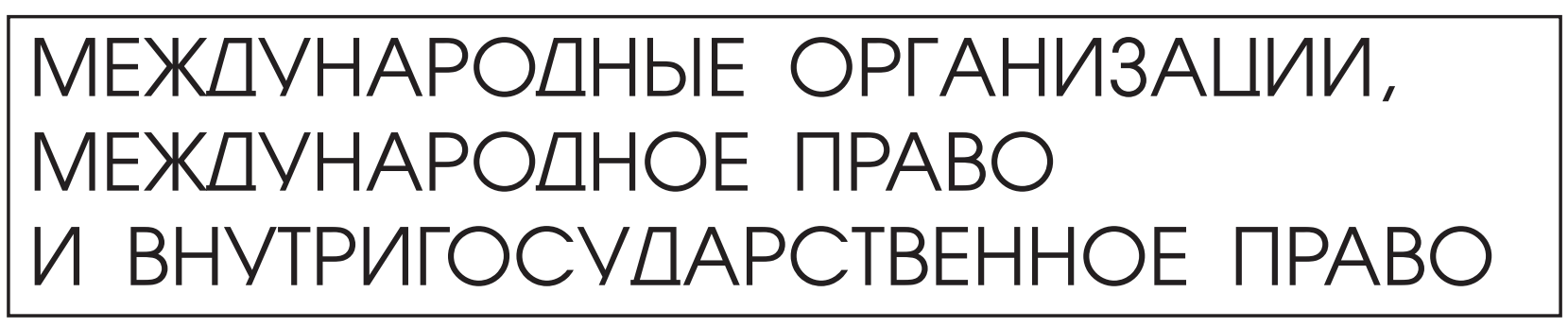

Костенко Н.И.

\title{
РОЛЬ МИРОВОГО СООБЩЕСТВА И РОССИИ В ПРОТИВОДЕЙСТВИИ ТОРГОВЛЕ ЛЮДЬМИ
}

\begin{abstract}
Аннотация. Предметом исследования являются: - соответствующие положения международно-правовых актов, посвященных борьбе с грубейшими нарушениями прав человека - торговля людьми; - отечественное уголовное законодательство об ответственности за торговлю людьми - научная литература по проблемам борьбы с работорговлей; - соответствующие статистические данные. Объектом исследования выступают представленный в международ-ном сообществе и России подход к формированию международной и начиональной уголовной политике в сфере борьбы с работорговлей, а также отномения мирового сообщества и России, возникающие в сфере реализации соответствующих международно-правовых актов и осуществления предупреждения исследуемого преступления. В основу исследования положен общенаучный диалектический метод познания, предполагающий изучение правовых актов и понятий в борьбе с работорговлей. Применялись логико-юридический (догматический), сравнительный и исторический методы. Новизна исследования заключается, прежде всего, в том, что это одно из первых исследований уголовной политики в сфере борьбы с работоргов-лей, а также проблем ее оптимизации. Во-первых, автор подчеркивает, что ООН в своих конвенциях и резолюииях должна настаивать на активизации и необходимости справедливого судопроизводства для решения проблем связанных с работорговлей. Во-вторых, автор обращзает внимание на необходимость признания и уважения прав потерпевших (детей и женщин) в соответствии с международными стандартами. B-третьих, законодатели стран мира обязаны запретить торговлю людьми и принять законы о жестком наказании виновных. B-четвертых, за умышленное совершение этого преступления в неко-торых его наиболее тяжких формах необходимо назначать наказание, соразмерное с наказанием за особо тяжкие преступления.
\end{abstract}

Ключевые слова: Искоренение, организованная преступность, международные стандарты, преступления, ратификация, криминальное явление, преступная сеть, принудительный труд, юридическая сила, работорговля.

Abstract: This article focuses on the following subjects:-Corresponding positions of international laws dedicated to the fights against the grossest violation of human rights - human trafficking;Russian criminal legislation on responsibility for human trafficking;- Scientific literature on the issues of fight against human trafficking; - Related statistical data.The object of this research is the approach towards formation of international and national criminal policy in the area of the fight against human trafficking presented in the international community and Russia, as well as relations between the global community and Russia that emerge in the area of realization of corresponding international legal acts and prevention of this crime. The scientific novelty consists in the fact that this is one of the first researches of criminal policy in the area of fight against human 
trafficking and the issues of its optimization. The author highlights the fact that in its conventions and resolutions the UN must insist on activation and necessity of fair justice for solution of issued pertaining to human trafficking.

Keywords: Legal authority, forced labor, criminal enterprise, eradication, organized crime, international standards, crime, ratification, criminal phenomenon, human trafficking.

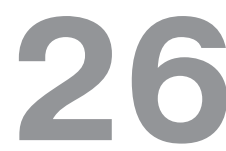
марта 2007 г. в штаб-квартире ООН в Нью-Йорке состоялось заседание Генеральной Ассамблеи, посвященное Международному дню празднования 200-летия отмены трансатлантической работорговли.

Спустя два столетия после того, как США и Британская империя запретили рабство, миллионы людей в мире все еще лишены основополагающих прав и свобод.

Генеральная Ассамблея провозгласила 25 марта Международным днем празднования отмены трансатлантической работорговли. В марте 1807 года Президент США Томас Джефферсон подписал закон о запрете работорговли. А чуть позже, тоже в марте, английский парламент одобрил законодательство, запрещающее работорговлю в Британской империи.

Эти шаги положило начало искоренению рабства на планете. В ходе трансатлантической работорговли, которая велась с пятнадцатого по девятнадцатое столетие, миллионы африканцев, главным образом из Западной Африки, были насильно перевезены на американский континент, за счет чего было достигнуто обогащение колониальных держав того времени.

Но, тем не менее, по данным Организации Объединенных Наций (далее $\mathrm{OOH}$ ), в наше время годовой оборот мировой работорговли составляет около 7 миллиардов долларов[1].

Почти два с половиной миллиона человек во всем мире являются жертвами современной работорговли. Их принуждают к насильственному труду и оказанию сексуальных услуг, и происходит это во всех регионах мира и во всех странах.
Генеральный секретарь ООН Пан Ги Мун призвал искоренить эту преступную практику - остановить торговцев людьми, лишить их источников финансирования и конфисковать их активы[2].

Проблема торговли людьми является одной из составляющих глобального мандата Управления $\mathrm{OOH}$ по наркотикам и преступности (далее УНП ООН). Указанное управление занимается решением вопросов и разработке рекомендаций и мер для стран - участниц ООН по борьбе с международной организованной преступности.

Являясь единственным Управлением $\mathrm{OOH}$, делающим упор в своей работе на вопросы уголовного правосудия применительно к борьбе с торговлей людьми и незаконным ввозом мигрантов, деятельность УНП ООН опирается на Конвенцию ООН против транснациональной организованной преступности, принятой в Палермо 12 декабря 2000 года и протоколы к ней: о предупреждении и пресечении торговли людьми, особенно женщинами и детьми, в целях сексуальной эксплуатации; против незаконного ввоза мигрантов на суши, море и воздуху [3].

УНП ООН оказывает государствам специализированную помощь, включая развитие местного потенциала, а также предоставление практического инструментария, стимулирующего трансграничное сотрудничество в расследовании и уголовном преследовании.

Новые подходы международного сообщества в борьбе с организованной преступностью определены в указанной Конвенции $\mathrm{OOH}$, и в протоколах. 
Принятие «Протокола о предупреждении и пресечении торговли людьми, в особенности женщинами и детьми, и наказании за нее» явилось важной вехой в попытках международного сообщества остановить торговлю людьми. Протокол вступил в действие с 25 декабря 2003 года. Россия подписала Протокол 12 декабря 2000 года (Распоряжение Президента РФ от 09.12.2000 № 556-рп), ратифицировала (Федеральный закон от 26.04.2004 № 26-Ф3). Протокол вступил в силу для России 25.06.2004 [4].

Это первый международный инструмент, наделенный обязательной юридической силой в котором согласована дефиниция термина «торговли людьми». Значение настоящего определения направлено на усиление процессов сближения национальных подходов в области совершенствования уголовного преследования, которое, в свою очередь, способствовало бы эффективному сотрудничеству в расследовании и уголовном преследовании в области дел по преступлениям торговли людьми. Так же целью Протокола является защита и содействие потерпевшим от преступлений торговли людьми на основе принципов соблюдения прав и свобод человека.

Протокол подписан и ратифицирован более чем 150 государствами, тем не менее, реализация его остается проблематичной.

На наш взгляд торговля людьми является криминальным явлением глобального масштаба, которое нарушает права миллионов мужчин, женщин и детей, подвергающихся эксплуатации в форме принудительного труда, принудительной проституции и порнографии, в торговле людьми для нелегальной трансплантации органов, в незаконном усыновлении, в недобровольном замужестве и в совершении преступлений. Незначительное число преступников были осуждены, а большинство их жертв так и не были выявлены и не получили соответствующую помощь.
Разрыв в оценке количества жертв торговли людьми и количества фактических дел во всем мире показывает, что современное рабство остается преступлением с очень высокой прибылью и с низким риском выявления. Под воздействием глобального экономического и финансового кризиса торговля людьми в целях эксплуатации интегрировалась в мировую экономику из-за возросшего спроса на дешевый и незащищенный труд как предпосылку экономического «выживания во, чтобы то ни было»[5] .

Торговля людьми - это современная форма рабства, которая сопровождается самыми грубыми и самыми жестокими нарушениями прав человека. По экспертным оценкам, организованные преступные группы зарабатывают на торговле людьми десятки миллионов долларов. Не вызывает сомнения, что эти средства наряду с доходами от торговли наркотиками и оружием составляют финансовую базу международного терроризма.

Торговля людьми и использование рабского труда очень часто тесно связаны между собой, так как целью сделок в отношении людей выступает их последующая эксплуатация.

Необходимо акцентировать внимание на том, что современное рабство способствует коррупции, незаконной организации миграции, уклонение от налогов, отмывание денег. На полученные от торговли людьми доходы, криминальные рынки наращивают свою роль в глобальной экономике. Торговля людьми становиться неистощимым источником прибыли, которая вновь и вновь инвестируется во все виды другой преступной деятельности, включая торговлю оружием и оборотом наркотиком. Полагаю, что это новый выгодный возобновленный бизнес преступной сети. Доходы от торговли людьми - это потенциальные источники финансирования терроризма. Вербовка молодых людей, детей, которы- 
ми торгуют для того, чтобы эксплуатировать их в террористических операциях. Террористические группы идеологически обрабатывают свои жертвы для подготовки террористов-смертников из самых уязвимых слоев населения, пострадавших от вооруженных конфликтов, это могут быть дети, потерпевшие родители, другие члены семьи, отчаявшиеся в своем горе и психологически готовые жертвовать собой.

По стандартам ООН, всякое государство обязано бороться с проявлениями работорговли во всех формах, в том числе и использованием принудительного труда. Основные требования $\mathrm{OOH}$ по ликвидации работорговли следующие:

1. торговля людьми должна быть официально запрещена, и за неё должно быть предусмотрено строгое наказание;

2. наказание за торговлю людьми должно быть соизмеримо с наказанием за тяжкие и особо тяжкие преступления, то есть достаточно строгим для сдерживания этой деятельности и адекватно отражающим отвратительный характер преступления;

3. правительство страны должно предпринимать серьёзные и неустанные усилия с целью ликвидации торговли людьми.

Правительственные и общественные организации, занимающиеся вопросами соблюдения прав человека, обязаны постоянно отслеживать развитие ситуации с торговлей людьми в мире. К сожалению, их деятельность ограничивается констатацией фактов. Реальная борьба с работорговлей и использованием принудительного труда сдерживается тем, что использование рабского труда снова стало экономически выгодным.

В нравственной жизни человечества работорговля, безусловно, имела и имеет крайне вредные последствия. С одной стороны, оно приводит к нравственной деградации людей, уничтожая в них чувство человеческого достоинства и стремление к труду на благо себя самого и общества, с другой - отражается неблагоприятно на рабовладельцах.

Думается, что среди исходных причин и социальных факторов, способствующих торговле людьми, можно назвать бедность, низкий уровень образования, ограничение возможности доступа к эффективной занятости, разница в уровне развития между странами и т.д.

Считаем, что было бы неверным утверждать, что только эта категория граждан попадает в сети торговцев. Торговля людьми как преступление актуальна для криминальных структур. Экономические трудности заставляют людей прибегать к рисковым моделям поведения, они сами создают торговцам условия для преступной деятельности. Полагаю, что торговля людьми базируется на незаконной миграции. Незаконные мигранты составляют особую группу риска. Они «выпадают» из правового поля и в этой связи находятся в полной власти работодателя и теневых криминальных структур, занимающихся незаконным оборотом рабочей силы. Такая эксплуатация может рассматриваться как одна из разновидностей работорговли. Противостоять торговцам « живым товаром» - значит, бороться с организованной преступностью.

Генеральная Ассамблея ООН 30 июля 2010 года приняла резолюцию, которой утвердила «Глобальный план ООН по борьбе с торговлей людьми»[6]. Данный глобальный план является приложением к резолюции. Он имеет широкое применение. План включает в себя, прежде всего действия, которые должные предпринимать государства, поддерживаемые международными организациями, гражданским обществом, СМИ и сознательными гражданами.

Члены ООН подтвердили свою приверженность к борьбе по ликвидации такого 
отвратительного преступления, каким является торговля людьми, особенно женщинами и детьми. И в свою же очередь заявили о своей решимости предупреждать торговлю людьми и бороться с ней, защищать жертв такой торговли и оказывать им помощь. Обеспечивать судебное преследование лиц, причастных к торговле людьми. Способствовать налаживанию партнерских отношений для расширения координации и сотрудничества. И в свою же очередь заявили о своем намерении воплотить свою политическую волю в конкретные действия путем принятия плана для:

- признания того, что «торговля людьми» означает осуществляемую в целях эксплуатации вербовку, перевозку, передачу, укрывательство и получение людей путем угрозы силой или ее применения или других форм принуждения, похищения, мошенничества, обмана, злоупотребления властью или уязвимостью положения, либо путем подкупа, в виде платежей или выгод, для получения согласия лица, контролирующего другое лицо;

- эксплуатации проституции или другие формы сексуальной эксплуатации, принудительный труд или услуги, подневольное состояние или извлечение органов;

- принятия срочных мер для предотвращения торговли людьми, защиты жертв такой торговли и судебного преследования, причастных к ней лиц и укрепления партнерских отношений в этих целях;

- устранения социальных, экономических, культурных, политических и других факторов, которые делают людей уязвимыми к торговле людьми, таких как нищета, безработица, неравенство, чрезвычайные гуманитарные ситуации, включая вооруженные конфликты и стихийные бедствия, сексуальное насилие, дискриминация по признаку пола и социальная изоляция, а также обстановка терпимости к насилию в отношении женщин, молодежи и детей;
- принятия и претворения в жизнь на национальном уровне и в надлежащих случаях на субрегиональном и региональном уровнях всеобъемлющих стратегий и программ предупреждения всех форм торговли людьми, согласующихся с соответствующими стратегиями. А также программами в области миграции, образования, занятости, гендерного равенства, расширения прав женщин и предупреждения преступности согласно соответствующим международным документам о правах человека;

- активизации и поддержки усилий по предупреждению торговли людьми в странах происхождения, транзита и назначения за счет акцентирования внимания на спросе, способствующем всем формам торговли людьми, и на спросе на товары и услуги, производимые в результате торговли людьми;

- защиты личной жизни и личности и обеспечения безопасности жертв торговли людьми во время и после уголовного преследования и для обеспечения, в надлежащих случаях, защиты ближайших членов семьи и свидетелей от возмездия со стороны лиц, причастных к торговле людьми, путем обеспечения их безопасности;

- обращения к государствам-участникам с настоятельным призывом рассмотреть возможность принятия законодательных или других надлежащих мер, позволяющих жертвам торговли людьми оставаться, в надлежащих случаях, на их территории, на временной или постоянной основе, в соответствии с положениями Конвенции и Протокола о торговле людьми;

- обеспечения принятия странами происхождения своих граждан, оказавшихся жертвами торговли людьми и гарантирования того, что такое возвращение будет осуществлено с надлежащим учетом вопросов безопасности и преимущественно добровольно, в соответствии с положениями Конвенции и Протокола о торговле людьми; 
- осуществления всех соответствующих правовых документов, устанавливающих уголовную ответственность за торговлю людьми, в частности посредством:

a) судебного преследования лиц, совершивших преступления в виде торговли людьми, с охватом всех форм эксплуатации и принятия, обеспечения соблюдения и укрепления законодательства, устанавливающего уголовную ответственность за торговлю людьми, особенно женщинами и детьми;

b) принятия законодательства и других мер, необходимых для установления уголовной ответственности за покушение на совершение такого преступления, за участие в совершении такого преступления в качестве сообщника и за организацию других лиц или руководство ими с целью совершения такого преступления, как предусмотрено в Протоколе о торговле людьми, Конвенции о ликвидации всех форм дискриминации в отношении женщин, Конвенции о правах ребенка и факультативных протоколах к ней, а также в других соответствующих документах;

c) борьбы с организованными преступными группами, причастными к торговле людьми, и судебного преследования этих групп;

- подтверждения важнейшей роли деятельности УНП ООН в глобальной борьбе с торговлей людьми.

Среди прочего, резолюция Генеральной Ассамблеи ООН учредила доверительный фонд для жертв торговли людьми, особенно женщинами и детьми, и предписывает УНП ООН предоставлять ежегодный глобальный отчет по борьбе с торговлей людьми.

Во Всемирном докладе о торговле людьми за 2014 год, опубликованном Управлением ООН по наркотикам и преступности (УНП OОН), говорится о том, что каждая третья из известных жертв торговли людьми - это ребенок, то есть наблюдается увеличение количества детских жертв по сравнению с 2007-2010 гг. Две из трех детских жертв девочки, и вместе с женщинами они составляют 70 процентов от общего объема жертв торговли людьми во всем мире[7].

«К сожалению, как показал доклад, в мире нет места, где дети, женщины и мужчины были бы защищены от торговли людьми, » - сказал исполнительный директор УНП ООН Юрий Федотов, - «Официальные данные, предоставленные УНП ООН национальными властями, отображают лишь выявленные случаи торговли людьми. Абсолютно очевидно, что масштабы современной работорговли намного больше».

Ни одна страна не застрахована от этой проблемы. По крайней мере, 152 страны происхождения и 124 страны назначения торговли людьми, а также более 510 потоков торговли людьми, охватывающих весь мир. Как правило, торговля людьми происходит в пределах национальных границ или в рамках одного региона, при этом с проблемой транснациональной торговли людьми преимущественно сталкиваются богатые страны[8].

В таких регионах, как Африка и Ближний Восток, торговля детьми является серьезным предметом озабоченности, поскольку процент детских жертв торговли людьми там составляет 62 процента.

Торговля людьми с целью принудительного труда также продолжала непрерывно расти в течение последних десяти лет. Жертв торговли вынуждают, среди прочего, к работе на промышленном производстве и строительстве, а также в качестве домашней прислуги и на текстильном производстве. Около 35 процентов выявленных жертв торговли людьми в целях принудительного труда - женщины.

Вместе с тем отмечаются некоторые различия по регионам: жертвы в Европе и Центральной Азии в основном являются предметом торговли в целях их сексуаль- 
ной эксплуатации, в то время как основным двигателем рынка в Восточной Азии и Тихоокеанском регионе является принудительный труд. В Северной и Южной Америке оба типа проявлены практически в равной мере.

Большинство потоков торговли людьми имеют межрегиональный характер, и более шести из десяти жертв переправляются, по крайней мере, через одну национальную границу. Подавляющее большинство осужденных торговцев людьми, а именно - 72 процента, - это мужчины - граждане той страны, в которой они осуществляют деятельность.

В докладе подчеркивается, что безнаказанность виновных по-прежнему представляет собой серьезную проблему. В 40 процентов стран фактически совсем не было зарегистрировано обвинительных приговоров, а за последние 10 лет не наблюдается глобальных мер реагирования на этот вид преступления со стороны органов уголовной юстиции, а это означает, что значительная часть населения остается уязвимой перед преступниками.

«Даже если большинство стран установили уголовную ответственность за торговлю людьми, многие люди продолжают жить в странах с законами, которые не соответствуют международным правовым стандартам, обеспечивающим им полную защиту, таким, как Протокол о торговле людьми, » - отметил господин Федотов.

«Нынешнее положение дел необходимо изменить » - добавил Федотов, - «Каждая страна должна принять Конвенцию $\mathrm{OOH}$ против транснациональной организованной преступности и ее Протокол, а также взять на себя обязательство по полному осуществлению ее положений»[9].

Как уже отмечалось, проблема транснациональной организованной преступности во все большей степени приобретает глобальный характер. Во-первых, транснациональная организованная преступность в большей или менее острой форме проявляется практически во всех странах мира, являясь серьезным реальным или потенциальным препятствием на пути их социально-экономического, политического и культурного развития. На мой взгляд, это предопределяет заинтересованность членов мирового сообщества в совместном поиске наиболее действенных путей и средств решения данной проблемы. Во-вторых, постоянно расширяется перечень преступных деяний, представляющих международную опасность (террористические акты международного характера, трансграничный оборот наркотиков, оружие и радиоактивных материалов, которые напрямую связаны с работорговлей). Думается, что борьба с такого рода преступлениями может быть по настоящему эффективна только при согласованных действиях большинства государств, при рациональном сочетании внутригосударственных и международных усилий.

В последние 15 лет отчетливо проявляется тенденция расширения и углубления международного сотрудничества в правоохранительной сфере, в первую очередь в борьбе с транснациональной организованной преступностью. Полагаю, что это обусловлено быстрым развитием интеграционных процессов в мире, расширением политических, экономических, культурных и гуманитарных связей, совершенствованием средств транспорта и связи, упрощением порядка выезда из стран, пограничных и таможенных формальностей, а также постепенным утверждением в международных отношениях приоритета общечеловеческих ценностей, идей справедливости и солидарности.

Сотрудничество государств в рассматриваемой области имеет объективную основу - их тесную взаимосвязь и взаимозависимость, которые влекут качественное 
изменение самой преступности, в том числе интернационализацию, т.е. возрастание в ней удельного веса международных элементов (например, совершение преступления на территории двух и более государств, укрывательство и сбыт похищенного или «отмывание» доходов от преступной деятельности за границей, попытки преступников скрыться от правосудия за рубежом и т.п.).

Криминализация общества создает широкий спектр внутренних и внешних угроз национальной безопасности многих стран. Одной из таких угроз является развитие и укрепление позиций организованной преступности, специализирующихся на совершении преступлений, связанных с торговлей людьми.

Торговля людьми - многогранное транснациональное преступление, выходящее за рамки одного государства, совершаемое организованными группами, и кроме того, крайне латентное преступление, обусловленное рядом взаимосвязанных факторов.

Анализируя два международных Пакта одобренных 16 декабря 1966 г. Генеральной ассамблеей ООН о правах человека: о гражданских и политических правах человека и об экономических, социальных и культурных правах[8] необходимо отметить, что они обязуют государства обеспечить любому лицу, права и свободы которого, признаваемые пактом, нарушены. Значительное место в обоих пактах уделено проблемам свободы труда. Пакт о гражданских и политических правах устанавливает, что никто не должен содержаться в рабстве (рабство и работорговля запрещается во всех видах); никто не должен содержаться в подневольном состоянии; никто не должен принуждаться к обязательному труду.

Согласно ст. 9 Международного пакта о гражданских и политических правах каждый человек имеет право на свободу и личную неприкосновенность. Никто не может быть подвергнут произвольному аресту или со- держанию под стражей. Никто не должен быть лишен свободы иначе, как на таких основаниях и в соответствии с такой процедурой, которые установлены законом.

Россия, как и другие развитые страны, крайне заинтересована в выработке комплексной системы мер эффективной защиты личности, общества и государства от подобных преступных посягательств, для чего требуется консолидация усилий, направленных на борьбу с работорговлей.

В соответствии с п. 1 ст. 22 Конституции РФ каждый имеет право на свободу и личную неприкосновенность. Согласно ст. 27 Конституции РФ каждый, кто законно находиться на территории Российской Федерации, имеет право свободно передвигаться, выбирать место пребывания и жительства. Каждый может свободно выезжать за пределы Российской Федерации. Гражданин Российской Федерации имеет право беспрепятственно возвращаться в Российскую Федерацию.

Для объективной оценки криминогенной ситуации в сфере торговле людьми в качестве важной предпосылки организации эффективной борьбы с указанным видом преступления необходимо получение достоверного знания о реальном состоянии и масштабах рассмотрения феномена.

Д. А. Оводков считает, что за последние время правоохранительными органами Российской Федерации накоплен, определенны опыт борьбы с торговлей людьми. Однако обобщение практики данного вида правоохранительной деятельности свидетельствует о неоднозначной правовой оценке, неумении правильно отграничить данные преступления от смежных с ними деяний [9].

На наш взгляд следует учитывать специфику России как страны транзита, происхождения и назначения живого товара.

Д.А. Оводков полагает, что прозрачность границ внутри СНГ и отсутствие визового 
режима приводит к тому, что большая часть фактов торговли людьми на этом пространстве осуществляется с законным пересечением границы и с действительными документами. Незначительная часть торговли людьми в этом случае может быть пресечена на границе и предотвращена с помощью мер пограничного контроля. Россия занимает особое место на перекрестках массовых миграционных потоков, именно через ее южные и восточные границы идет основной поток нелегальных мигрантов.

Учитывая данные факторы и понимая взаимосвязь незаконной миграции с торговлей людьми и множеством других преступлений, торговля людьми совершается, как правило, по следующей схеме: вербовка и вывоз-перевозка- прием и эксплуатация. Составные части данного преступления остаются неизменными независимо от того, перемещается ли жертва преступником в порядке одной страны либо в другое государство. Разница состоит в том, что во втором случае преступнику необходимо обеспечить пересечение жертвой государственной границы (как правило, незаконно).

В России вопросы противодействия торговле людьми включены в качестве одного из направлений сотрудничества в межправительственные соглашения о взаимодействии в борьбе с преступностью, заключенными с более чем 70 странами[10].

Анализ судебно-следственной практики, который вытекает с единого отчета о результатах борьбы с организованной преступностью за январь-июнь 2015 г. (нарастающим итогом с начала года) по России показал, что на стадиях вербовки и перевозки распознать торговлю людьми практически не возможно, а если и содержатся подобные признаки, то доказательственная база данной деятельности отсутствует. Большинство жертв данного тягчайшего преступления и сами не предполагают той участи, которая им уготована в стране назначения. Торговцы людьми реально становятся очевидными субъектами данного преступления только в стране назначения, где непосредственного происходит эксплуатация людей[11].

Торговля людьми (ст. $127^{1}$ УК РФ) является новеллой для российского уголовного законодательства. Универсальные нормы об ответственности за торговлю людьми и использования рабского труда были внесены Федеральным законом от 8 декабря 2003 г. «О внесении изменений и дополнений в Уголовный кодекс Российской Федерации»[12], что во многом было следствием исполнения международных обязательств, взятых на себя Россией.

Причин и условий, способствующих совершения преступления, предусмотренного ст. 127. ${ }^{1}$ УК РФ (торговли людьми) достаточно много.

Во-первых, это открытость границ Российской Федерации со странами СНГ; во-вторых, усиление миграционных потоков, как внутри России, так и между государствами; в-третьих, глобализация организованной преступности, расширение возможностей криминальных групп в организации устойчивых каналов поставки «живого товара».

Родовым объектом торговли людьми являются конституционные права и свободы личности, видовым - свобода, честь и достоинство личности. Непосредственным объектом данного преступления является право на личную (физическую) свободу.

Дополнительным объектом торговли людьми могут выступать право на жизнь и здоровье, право на труд, отношение собственности и т.п.

Предметом преступления в данном случае является потерпевший.

Объективная сторона преступления может заключаться в совершении хотя бы одного из действий, перечисленных в ч. 1 
статьи $127^{1}$ УК РФ. Купля-продажа человека представляет собой договор (в любой форме), по которому продавец передает потерпевшего в незаконное владение покупателя за определенную денежную сумму. В качестве платежа может выступать и определенный имущественный эквивалент, т.е. выгода имущественного характера (движимое и недвижимое имущество) а также другие формы - бесплатное получение чего-либо, отказ от имущественного или денежного долга и т.д.

Вербовка предполагает набор людей по найму для выполнения каких-либо работ, оказания определенных услуг. Обычным способом вербовки является предложение и хорошо оплачиваемой работы в качестве нянь, служащих, официантов и т.д. в странах ближнего и дальнего зарубежья.

Среди торговли людьми наиболее распространенными видами является торговля женщинами и детьми для занятия проституцией. С этой целью их продают и вывозят в другие страны, комплектуют дома терпимости.

Формы преступной деятельности в сфере торговли людьми весьма разнообразны: от безобидных фотоконкурсов до дерзких похищений и приобретения «живого товара» у родственников. Нередко девушки, отправляющиеся на поиски работы в страны Западной Европы, оказываются в элементарных борделях Голландии или Балкан.

Второй способ вербовки - «брачные агентства», иногда называемые агентствами «невест по почтовой переписке» или агентствами по предоставлению международных услуг. Согласно некоторым исследованиям, все агентства «невест по почтовой переписке» из республик бывшего Советского Союза находятся под контролем сети организованной преступности.

Третий способ вербовки осуществляется индивидуально лицами, откровенно нуждающимися в деньгах или же имеющими долги перед российскими и зарубежными партнерами.

Четвертый, нарастающий, способ вербовки получил название «вторая волна», в ходе которой проданные женщины возвращаются домой, чтобы нанять на работу других женщин. Процесс пере вербовки отработан очень тщательно.

Пятый способ вербовки - откровенные объявления о найме на работу в качестве проституток. Например, такие: «Требуется группа девушек приятной внешности для работы за бугром. Заработная плата от тысячи долларов. Жилье и питание за счет фирмы».

Шестой способ вербовки осуществляется через публичные мероприятия - конкурсы красоты, конкурсы фотографий, наборы в студии фотомоделей, манекенщиц и другие

Седьмой способ вербовки для трудоустройства - отбор девушек по фотографиям, которые впоследствии отправляются для отбора соответствующим заинтересованным заказчикам.

Наиболее популярный способ вербовки происходит через интернет сайты. Множество фирм и агентств, имеющих и не имеющих на то разрешения, завлекают на любую работу в любую страну. Объявления предлагают женщинам и девушкам от 18 до 30 лет высокооплачиваемые и безопасные вакантные места «неквалифицированных рабочих», прислуги, стриптизерш, танцовщиц в ночных клубах или в фирмах досуга. Некоторые женщины становятся жертвами обмана, полагая, что их нанимают для работы на законных основаниях или помогают заключить брак за границей. Другие женщины осведомлены о том, что они будут вынуждены отрабатывать существенные затраты на трудоустройство и перевозку, но не имеют представления об условиях труда. Многих завлекают обещаниями хорошей работы, и они не подозревают, что 
их документы будут конфискованы и их «повяжут» долговыми обязательствами или будут избивать. Эти женщины обычно незаконно выезжают или проживают в стране назначения, что усиливает их зависимость от торговцев. Широко используется долговая зависимость для контроля над «живым товаром» и получения постоянной прибыли от его эксплуатации.

Торговцы женщинами и детьми используют разнообразные способы переправления своих жертв через национальные и международные границы. Иногда они действуют через формально респектабельные агентства по трудоустройству, турагентства, фирмы по организации отдыха и развлечений или брачные компании. Для пересечения международных границ используются легальные документы, после чего жертвы либо исчезают, либо нарушают визовый режим. Но торговцы используют и фальшивые (или исправленные и подделанные) документы для получения подлинных виз.

Субъективная сторона характеризуется прямым умыслом и специальной целью эксплуатацией потерпевшего. Под эксплуатацией человека понимается использование занятия проституцией другими лицами и иные формы сексуальной эксплуатации, рабский труд (услуги), подневольное состояние. Однако наличие специальной цели необходимо только для таких форм преступного проведения, как вербовка, перевозка, укрывательство или получения потерпевшего. Купля-продажа и иные сделки в отношении человека являются преступными независимо от целей, преследуемых виновным.

Среди квалифицирующих признаков, названных в ч. 2 и 3 ст. 127 'УК РФ, специфическими являются:

- в отношении двух или более лии (n. «а» ч. $2 \mathrm{~cm} .127^{1}$ УК РФ), осуществление деяния одновременно с двумя или более потерпевшими при наличии единого умысла;
- в отношении несовершеннолетнего (n. «б»ч. $2 \mathrm{~cm} .127^{1}$ УК $\left.Р \Phi\right)$, лица, не достигшего совершеннолетия. Сведение о возрасте несовершеннолетнего для квалификации не требуется;

- лииом с использование своего служебного положения (n. «в» ч. $2 \mathrm{~cm} .127^{1}$ УК $P \Phi$, должностным лицом, постоянно, временно или по специальному полномочию осуществляющие функции представителя власти либо выполняющие организационно-распорядительные, административно хозяйственные функции в государственных органах, органах местного самоуправления, государственных и муниципальных учреждениях, а также в Вооруженных Силах РФ, других войсках и воинских формированиях РФ. Лицом, выполняющим управленческие функции в общественных, религиозных, коммерческих организациях, негосударственных организациях;

- совершение преступления с перемещением потерпевшего через Государственную гранииу РФ или с незаконным удержанием его за граниией (n. «г»ч. 2, ст. $127^{1}$ УК РФ. Перемещение через Государственную границу образует квалифицирующий признак независимо от того, как происходило это перемещение: с территории РФ или в обратном направлении, а также транзитом. Через границу со странами дальнего зарубежья или со странами СНГ;

- с использованием поддельных документов, а равно с изъятием, сокрытием либо уничтожением документов, удостоверяющих личность потерпевщего (n. «д»ч. 2 cm. $127^{1}$ УК РФ). Изъятие, сокрытие либо уничтожение документов, удостоверяющих личность потерпевшего, - один из самых опасных способов, который наряду с насилием или угрозой с насилием или угрозой ставит совершеннолетнего потерпевшего в зависимое положение, лишает его возможности разорвать кабальный контракт, возвратиться в страну по своему желанию; 
- с применение насилия или с угрозой его

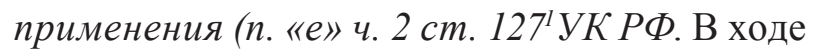
торговли людьми может применяться насилие, не опасные для жизни или здоровья, причиняться легкий вред здоровью или вред здоровью средней тяжести, а также угроза любым насилием, в том числе убийством;

- в целях изъятия у потерпевшего органов или тканей n. «ж» ч. $2 \mathrm{~cm} .127^{1}$ УК РФ. Для квалификации действий виновного по данному пункту статьи не требуется непосредственного осуществления трансплантации, достаточно установление специальной цели;

- в отношении лица, заведомо для виновного находящегося в беспомощном состоянии либо в материальной или иной зависимости от виновного (п. «з» ч. 2 ст. $127^{1}$ УК РФ). Беспомощным состоянием считается такое состояние, когда потерпевший в силу болезни, малолетнего возраста, старости и иных обстоятельств не в состоянии оказать активное сопротивление виновному;

- в отношении женщин, заведомо для виновного находящейся в состоянии беременности (п. «и» ч. 2 ст. $127^{1}$ УК РФ. Для квалификации по данному пункту требуется установить достоверность знание виновного такого обстоятельства, как беременность потерпевшей - до или в момент торговли.

В части 3 статьи $127^{1}$ УК РФ указаны квалифицирующие признаки, которые предусмотренные частью первой и второй данной статьи:

- повлекшие по неосторожности смерть, причинение тяжкого вреда здоровью потерпевшего или иные тяжкие последствия (n. «a» $.3 \mathrm{~cm} .127^{1}$ УК РФ). Указанное преступление совершается с двумя формами вины: умыслом по отношению к торговле людьми. Причинение тяжкого вреда здоровью или наступления смерти по неосторожности. Для квалификации необходимо установить, что указанные последствия явились результатом торговли людьми;
- совершенные способом, опасным для жизни и здоровья многих людей (n. «б»ч. 3 $\mathrm{cm} .127^{1}$ УК РФ). Опасность для жизни людей может выражаться:

1) в способе перевозке потерпевших;

2) в способе физического сокрытия потерпевшего. Потерпевшие могут содержаться в условиях, создающих реальную опасность для их здоровья и жизни. Для их сокрытия могут применяться опасные для жизни и здоровья методы.

- совершение организованной группой (n. «в» $4.3 \mathrm{~cm} .127^{1}$ УК РФ). В соответствии со ст. 35 УК РФ преступление признается совершенным организованной группой, если оно совершено устойчивой группой лиц, заранее объединившихся для совершения одного или нескольких преступлений. В данном случае - торговлей людьми. Любое лицо организованной группы, принимавшее участие в торговле людьми, независимо от его роли, подлежит ответственности как соисполнитель преступления.

В примечании 1 к ст. $127^{1}$ УК РФ сформулированы условия освобождения от уголовной ответственности в случае деятельного раскаяния лица, совершившего преступления, предусмотренного ч.1 или п. «а» ч. 2 указанной статьи. Лицо, впервые совершило преступление и добровольно освободившее потерпевшего или способствовало раскрытию совершенного преступления, освобождается от уголовной ответственности, если в его действиях не содержится иного состава преступления.

Преступления, предусмотренные ч. 1 и 2 ст. $127^{1}$ УК РФ, относятся к числу тяжких преступлений, ч. 3 ст. $127^{1}$ УК РФ - особо тяжких.

Но в тоже время в российском обществе звучат призывы к ужесточению наказания за торговлю людьми. Напомним, ООН классифицирует такую деятельность как преступление против человечности. 
DOI: $10.7256 / 2226-6305.2016 .1 .17735$

При цитировании этой статьи сноска на doi обязательна

Международное право и международные организации•1•2016 International Law and International Organizations

На основании изложенного полагаю взять за основу проблемы сегодняшнего дня устоявшейся работорговле и на очередном заседании Генеральной ассамблеи ООН принять конвенцию о борьбе работорговлей всеми государствам предложить четыре главные задачи:

- во-первых, законодателям всех стран мира принять законодательство, запрещающее повсеместную торговлю людьми и жестко за нее наказывать;

- во-вторых, за умышленное совершение преступления в некоторых его наиболее тяжких формах нужно назначать наказание, соразмерное с наказанием за особо тяжкие преступления;

- в-третьих, за умышленное совершение любого акта торговли людьми законодатели должны назначать наказание, являющееся достаточно строгим для сдерживания и адекватно отражающим отвратительный характер преступления;

- в-четвертых, нужно предпринимать серьезные и неустанные усилия с целью полной ликвидации этого отвратительного промысла - торговли людьми.

\section{Библиография:}

1. Интернет источник /http://novoteka.ru/seventexp/11050256.

2. Интернет источник/ http://novostink.ru/mir/78435-rabotorgovlya-v-21-veke-zayavlenie-genseka-oon-iprizyv-iskorenit-trafiking.html\#ixzz3wdZSVR46.

3. Международное публичное право. Сборник документов: в 2 ч. Ч. II/ сост. и авт. Вступ. Статьи К.А. Бекяшев, Д.К. Бекяшев. М.: ТК Велби. Изд.-во Проспект. 2006 г. С. 1939-1971.

4. Интернет источник/ http://www.un.org/russian/documen/convents/ protocoll.htm.

5. Материалы международного круглого стола «Совершенствование сотрудничества между компетентными органами международных универсальных и региональных организаций в борьбе с торговлей людьми». М. 2012 г.

6. Интернет источник / http://daccess-ods.un.org/TMP/2512594.46144104.html.

7. Интернет источник /http://www.unodc.org/unodc/data-and-analysis/glotip.html.

8. Интернет источник/http://proksk.ru/pravovaia_statistika/otcheti_prest_2015/.

9. Интернет источник/http://proksk.ru/pravovaia_statistika/otcheti_prest_2013/.

10. Международное право в документах: Учебное пособие/ Сост.: Н.Т. Блатова, Г.М. Мелков. 2-е из., перер. и доп. М.: ИНФРА-М, 1997. С.101-122.

11. Интернет источник/ http://www.crime.vl.ru/index.php?c=1\&more $=1 \& p=4262 \& p b=1 \& t b=1$.

12. Интернет источник/http://base.consultant.ru/cons/cgi/online.cgi?base= LAW;n=122992;req=doc. 